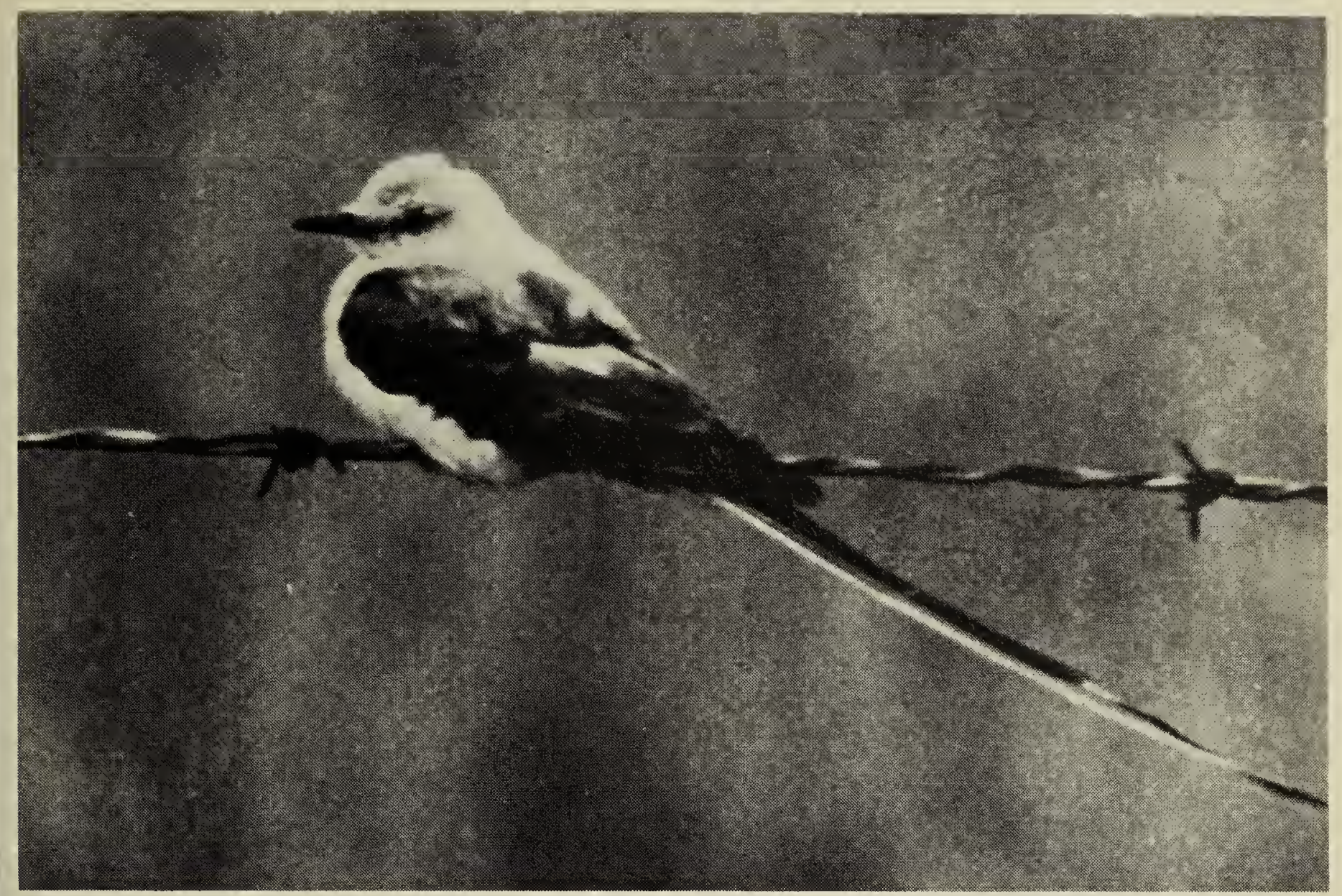

\title{
ANOTHER SASKATCHEWAN RECORD OF THE SCISSOR-TAILED FLYCATCHER
}

VICTOR C. FRIESEN, P.O. Box 65, Rosthern, Saskatchewan. SOK 3R0

On 28 June 1981 our family - my mother, Anna Friesen, my brother and sister-in-law, Ernie and Phyllis, and I were returning from a Sunday afternoon drive in the Rosthern, Saskatchewan, area. At 1740 we were proceeding north along the grid road which leads from the national historic site at Fish Creek. We had already passed the old Fish Creek church at the former ferry landing and were driving slowly along at $35 \mathrm{~km} / \mathrm{h}$ through this interesting countryside.
Mentally I was ticking off the identification of birds seen along the way. Two Turkey Vultures were riding the updrafts from the cliffs of the South Saskatchewan River, for the road here skirts the east bank and a pair of Black-billed Cuckoos flew in close pursuit from one aspen bluff to another.

Then $5 \mathrm{~km}$ south of the junction of the grid road and Highway No. 312 at Gabriel's Bridge, I spotted ahead of us a whitish-gray bird with black wings. It 
was sitting on the top strand of the barbed-wire fence which borders the east side of the road. I thought of a Loggerhead Shrike, but the body seemed to be a lighter gray, and on coming closer, I recognized its outline to be that of a flycatcher - a Scissor-tailed Flycatcher!

I had now driven past it, but immediately I stopped the car, walked towards it, and observed it with my $6 \times 30$ binoculars. The distance was about 10 m. A bright hazy sun at my back made for good viewing conditions. Not being familiar with the species except from having seen it in my bird books, I was not sure at that moment of all its distinctive features. This bird's tail was relatively short, but I did note that it was slightly longer than the rest of the bird. (My brother and I later, when observing the flycatcher together, estimated the tail's length to be $15-17 \mathrm{~cm}$.) One "blade" of the scissors was 1-2 cm shorter than the other one. The tail did not hang down but stuck out slantwise, as in Singer's illustration of an immature specimen in Birds of North America. ${ }^{9}$

I recalled that the Scissor-tailed Flycatcher should have some pink markings, but as it continued to sit on the wire, facing in my general direction, I could distinguish none at all. I noted the pearly-gray colouration of the back of its head and of the back itself. The underparts were lighter still, with the lower belly showing a buffy tinge. The blackish wings showed edgings of white.

Then the bird dropped to the ground to pick up a beetle and returned to its perch. As it flew I saw very pale pink wing linings and, more noticeably, a salmon-red patch underneath where the wing joins the body - the "axillars." Confident now that I had seen what I could, I stepped back to the car to pick up my Peterson's Field Guide to Western Birds and check my findings. ${ }^{7}$

As I returned to the bird a few minutes later, a truck came up at, high speed. I thought this would end my observations, but when the dust cleared, the bird was sitting as before, unperturbed. (I was to learn that evening from Pough that these flycatchers "often sit on roadside fence wires, oblivious of passing cars." Bent says it is "quite familiar and unafraid." $)$

My brother now joined me with his $7 \times 50$ binoculars, and we spent a further 15 min. observing the bird, again at close range. Since the field behind the fence was new breaking which exposed many beetles and grasshoppers to easy view, the scissor-tail had no trouble in finding its food. Six times it left its perch to secure an insect from the ground, then sat once more, sometimes on the lower wire as well, sometimes on the near fencepost. Thus we had a chance to view it from all angles. Its tail, however short, seemed like overlapping black and white ribbons during flight, and it scissored apart quite markedly. The ends of the fork curved out slightly in lyre-like fashion.

As for these birds feeding off the ground, Bent quotes Samuel $N$. Rhoades, who "observed them for hours gleaning insects in the open pastures and salt flats ..., alighting without hesitation in the short grass to secure or devour their food." "We left off our own observations when the flycatcher flew out a distance into the field and came down in a series of zigzags to alight on a hummock of sod. Before driving away, I wrote down the details of the sighting.

At home that same day I checked further into references concerning the Scissor-tailed Flycatcher. Godfrey lists its status in Canada as "casual or accidental," its breeding range being the southern United States (Colorado and Kansas and south), and does not include an illustration in his Birds of Canada. ${ }^{3}$ He does include records of six sightings from the Prairie Provinces (four from Manitoba and two from Alber- 
ta), but these numbers have increased since.

There had been four previous sightings in Saskatchewan. They occurred near Milestone (1970), Lumsden (1975), Tugaske (1978) and Saskatoon $(1980) .^{2} 65{ }^{4}$ Thus this is the fifth sighting for the province and the most northerly one.

The Scissor-tailed Flycatcher is by no means a stranger to even the far northern parts of the Prairie Provinces, however. Bent describes it as having "wandered widely"; 1 and Seton quotes Professor Bell of the Canadian Geological Survey, 1882, who writes: "I have learned since that these remarkable birds were occasionally seen at the posts of the Hudson's Bay Company, all the way west to the valley of the Mackenzie River."13 Canada's first specimen was obtained at York Factory on Hudson Bay in 1880.

Altogether there have been 14 records for Manitoba, including five specimens collected. ${ }^{2}$ The last record was near Whitemouth in 1979 and followed the previous record by 27 years. ${ }^{12}$ Alberta has three records, one of them also occurring in the northern part of the province, at Fort Chipewyan in $1952 .{ }^{10} \mathrm{~A}$ previous sighting occurred at Claresholm in 1943, and the last sighting occurred, like this one, along the South Saskatchewan River near Bow Island in 1964."

There have been no specimens collected in either Alberta or Saskatchewan but reliable photographs were taken of the Saskatoon bird. Personal commitments prevented me from returning later that evening to the location where I had seen the Scissortailed Flycatcher. When I did go back the next day, with a camera and telephoto lens, the bird was nowhere to be found.
The number of fairly recent sightings in our province (and one in Manitoba) could indicate that this is a species that bird watchers should be on the lookout for. For, as Salt concludes about it in his Birds of Alberta: "Those who observe this colorful bird in the Prairie Provinces are fortunate indeed." 10

'BENT, A. C. 1963 (reprint of 1942). Life histories of North American flycatchers, larks, swallows, and their allies. Dover, New York. 555pp.

2BRADLEY, J. E. 1971. A sight record of the Scissor-tailed Flycatcher for southern Saskatchewan. Blue Jay 29:34.

${ }^{3}$ GODFREY, W. E. 1966. Birds of Canada. Nat. Mis. Canada. Bull. 203, Ottawa. 428pp.

${ }^{4}$ HARRIS, W. C. 1981. Prairie Provinces region. Am. Birds 35:195-196.

${ }^{5}$ HEDGER, H. 1979. Scissor-tailed Flycatcher at Tugaske, Saskatchewan. Blue Jay 37:128.

${ }^{6}$ MacAULAY, A. J. Sight record of the Scissor-tailed Flycatcher for Saskatchewan. Blue Jay 34:95.

'PETERSON, R. T. 1961. A field guide to western birds. Houghton Mifflin, Boston. 366pp.

${ }^{8}$ POUGH, R. H. 1949. Audubon bird guide, eastern land birds. Doubleday, Garden City, N.Y. 312pp.

${ }^{9}$ ROBBINS, C. S., B. BRUUN, H. S. ZIM, and A. SINGER. 1966. Birds of North America. Golden Press, New York. 340pp.

${ }^{10}$ SALT, W. R., and J. R. SALT. 1976. The birds of Alberta. Hurtig, Edmonton. 498pp.

"SEALY, S. G. Third record of Scissor-tailed Flycatcher in Alberta. Blue Jay 26:82.

${ }^{12}$ TAYLOR, P. 1979. Scissor-tailed Flycatcher near Whitemouth, Manitoba. Blue Jay 37:228.

${ }^{13}$ THOMPSON, E. E. (E. T. Seton). 1975 (reprint of 1891). The birds of Manitoba. Premium Ventures, Winnipeg. 643pp. 